\title{
The Pivotal Part of Global Direct Investment - A Research Pre \& Post Liberalization Era
}

\author{
R S Ch Murthy Chodisetty, B Harshini Reddy
}

\begin{abstract}
Global investments are playing an important role in the growth of Indian economy better than other nation's economy in the present. More nations are providing more savings and attracting global investments. The requirement of global direct investments are deepening Inflows rate in any nations in the world. Global direct investments are specified a route between global inflows and savings in the country. In the process of Global economic development global investments helped to cover to Indian savings and provide entry routes in to India for development growth of Indian economy. These papers mainly focus on what is the position of FDI flows in pre and post liberalization period.
\end{abstract}

Keywords: FDI in India, Pre Liberalization, Post Liberalization. JEL Codes: F-21, D-92, E-22

\section{INTRODUCTION}

The government of India was initiation of introducing LPG in India. The main important role in the introducing LPG is increase foreign direct investments and industrial growth and Indian GDP.

FDI Explored Unidirectional relationship exists between FDI and GDP and FDI and EXR. Structural break was found in 1991-92 which is statistically significant year in terms of FDI in India. Hence, the New Economic Policy initiated in 1991-92 had made a significant impact on FDI in India.

\section{ROUTES OF FDI IN INDIA:}

\section{Automatic Route:}

By this route FDI is allowed without prior approval by Government or Reserve Bank of India, (GDR, ADR, IDR, FII, OFF-SHORE FUNDS), FDI reforms to push India-US trade: USIBC.

\section{Government Route (FIPB/SIA):}

Prior approval by government is needed via this route. Foreign Investment Promotion Board is the responsible agency to oversee this route. (SIA-Secretariat for Industrial Assistance)

\section{REVIEW OF LIERATURE}

Anitha. R (August-2012): This paper was indentifying Global direct investment flows in the india before LPG and after LPG. The main important concept of this study is what is the position of Global FDI inflow and treand analysis of

Revised Manuscript Received on April 12, 2019.

R S Ch Murthy Chodisetty, Assistant Professor, School of Management Studies, Sreenidhi Institute of Science and technology, Hyderabad, Telangana, India.(E-Mail: chodisetty.b4u @ gmail.com)

B Harshini Reddy, Student, B.Tech -III Year, Department of IT, Sreenidhi Institute of Science and technology, Hyderabad, Telanagana, India. (E-Mail: harshiniboddireddy@gmail.com) future five years. I am using Autoregressive Integrated Moving Average (ARIMA) forecasting technique.

Maniam \& Amitiava Chatterjee (1998): This paper is identified on the factors effecting on Global FDI flows in American states in to India. What are the factors are influencing Global FDI in to India and playing an important role in India.

Ajay shah \& Lla Patnaik (2004): The study detailed How Does the FDI Affect Economic Growth" suggest that the effectiveness of the FDI depends on the stock of human capital in the host country. Capital is above certain threshold and the FDI positively has contributed to growth. The FDI leads to the growth of technology spillovers that increase factor of productivity. They conclude that human capital could educate labor force and if necessary new technology and management skill are to be absorbed.

Chandana Chakraborty and Peter Nunnenkamp (2008): This paper is said that booming foreign direct investment in post-reform India is widely believed to promote economic growth.

Kali Ram Gola, Mridul Dharwal (2013): The main purpose of the study is to investigate the impact of FDI on economic growth in India, from the period of 1990 to 2011. It affects the economic growth by stimulating domestic investment, increasing human capital Formation and by facilitating the technology transfer in the host countries.

\section{OBJECTIVES OF THE STUDY}

1. To know the flow of investment in India.

2. To compare FDI inflows during the post liberalization period and pre liberalization period and forecast FDI inflow in India for future 5 years

\section{RESEARCH METHODOLOGY}

a. Data Collection for the study:

- World Bank website.

- Make in India Concept, concepts

- Central Statistical Organization (CSO)

- Investopedia.

- Wikipedia.

b. Tools and Techniques are used:

- Growth Rate

- Compound Growth Rate

- Autoregressive Integrated Moving Average

c. Period of the study:

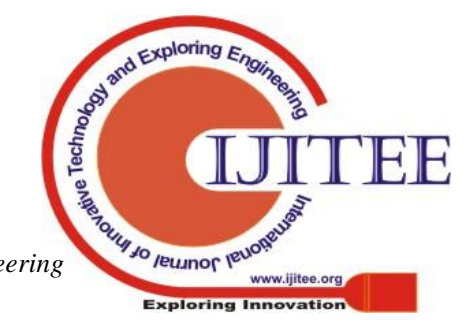


The period of the study will be 38 years i.e., 1980 to 2018 . India was said to have received insufficient FDI inflows. Therefore it is very much necessary to look back the trend of India's FDI inflows for the period 1980 to 2017 and to evaluate its potential factors determining FDI attraction and thereby bringing out a clear picture on the competitive status of India in FDI attraction among selected Asian nations.

\section{OBJECTIVE WISE ANALYSIS \& RESULTS}

Table No: 1.Share of Top Investing Countries (Fdi Equity Inflows)

\begin{tabular}{|c|c|c|c|c|c|c|}
\hline Rank & Country & $\mathbf{2 0 1 5 - 2 0 1 6}$ & $\mathbf{2 0 1 6 - 2 0 1 7}$ & $\mathbf{2 0 1 7 - 2 0 1 8}$ & $\begin{array}{c}\text { Cumulative } \\
\text { Inflows of FDI }\end{array}$ & $\begin{array}{c}\text { \% } \\
\text { of Total } \\
\text { Inflows }\end{array}$ \\
\hline 1 & Mauritius & 54,706 & 105,587 & 102,492 & 688,442 & $34 \%$ \\
\hline 2 & Singapore & 89,510 & 58,376 & 78,542 & 393,584 & $18 \%$ \\
\hline 3 & Japan & 17,27 & 31,588 & 10,371 & 152,630 & $7 \%$ \\
\hline 4 & U. K. & 5,938 & 9,953 & 5,473 & 131,018 & $7 \%$ \\
\hline 5 & Netherlands & 17,275 & 22,633 & 18,048 & 135,215 & $6 \%$ \\
\hline 6 & U.S.A & 27,695 & 15,957 & 13,505 & 124,037 & $6 \%$ \\
\hline 7 & Germany & 6,361 & 7,175 & 7,391 & 59,435 & $3 \%$ \\
\hline 8 & Cyprus & 3,317 & & 2,680 & 49,411 & $3 \%$ \\
\hline 9 & France & 3,937 & 4,112 & 3,297 & 33,934 & $2 \%$ \\
\hline 10 & UAE & 6,528 & 4,539 & 6,767 & 32,953 & $2 \%$ \\
\hline \multicolumn{2}{|l}{ Total FDI Flows } & $\mathbf{2 6 2 , 3 2 2}$ & $\mathbf{2 9 1 , 6 9 6}$ & $\mathbf{2 8 8 , 8 8 9}$ & $\mathbf{2 , 0 7 5 , 9 1 1}$ & \\
\hline
\end{tabular}

Source: DIPP website, FDI fact sheet.

Graph No: 1.Share of Top Investing Countries (Fdi Equity Inflows)

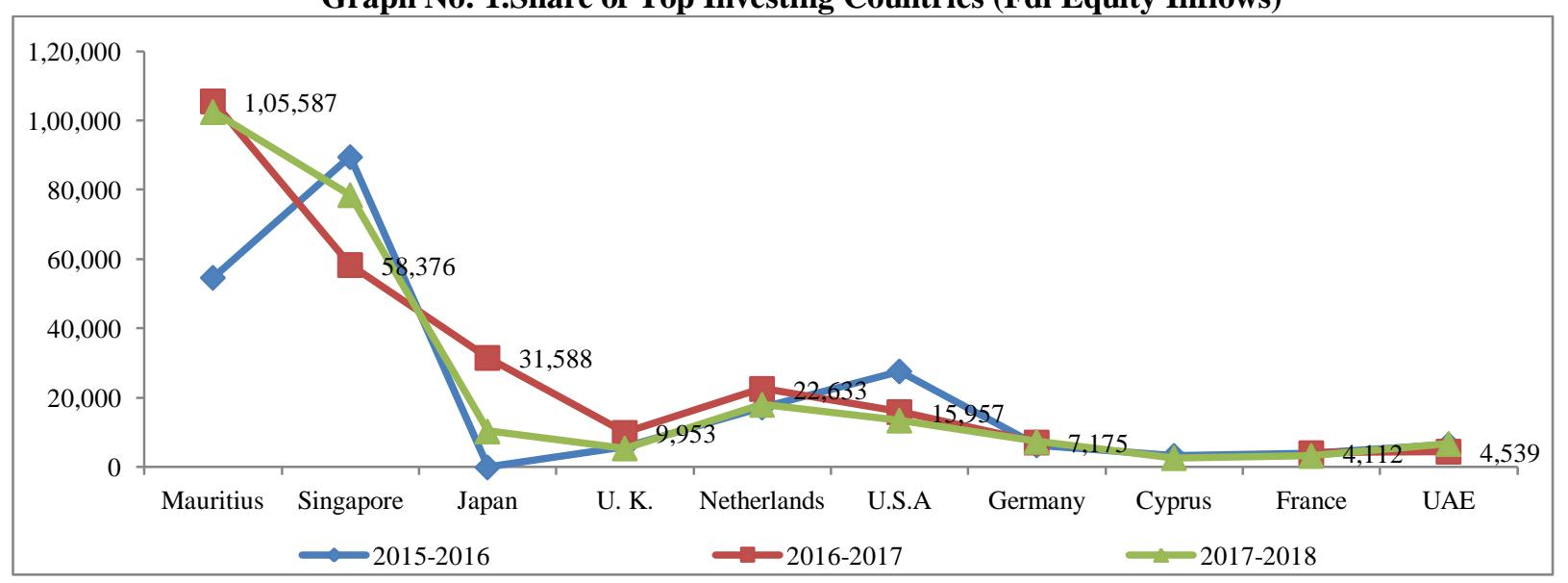

Analysis \& interpretation: The above table and graph shows that highest amount of FDI in India from 2016-2017 to 2017-2018 came from Mauritius. Mauritius had secured first place with 34 percent in the above said period. While Singapore, Japan, UK and Netherlanders are 18\%, 7\%, 7\% and $6 \%$ respectively.

Table No: 2. Sectors attracting highest fdi equity inflows

\begin{tabular}{|c|l|c|c|c|c|c|}
\hline \multirow{2}{*}{ Rank } & \multicolumn{1}{|c|}{ Sector } & $\mathbf{2 0 1 5 - 2 0 1 6}$ & $\mathbf{2 0 1 6 - 2 0 1 7}$ & $\mathbf{2 0 1 7 - 2 0 1 8}$ & $\begin{array}{c}\text { Cumulative } \\
\text { Inflows of } \\
\text { FDI }\end{array}$ & $\begin{array}{c}\text { \% of } \\
\text { Total } \\
\text { Inflows }\end{array}$ \\
\hline 1 & Services Sector ** & 54,706 & 58,214 & 43 & 249 & $18 \%$ \\
\hline 2 & Computer software \& Hard ware & 89,510 & 24,605 & 359 & 817 & $8 \%$ \\
\hline 3 & Telecommunications & 17,27 & 37,435 & 39 & 670 & $8 \%$ \\
\hline 4 & Construction Development: & 5,938 & 703 & 176 & 459 & $7 \%$ \\
\hline 5 & Automobile Industry & 17,275 & 10,824 & 39 & 748 & $5 \%$ \\
\hline 6 & Trading & 27,695 & 15,721 & 169 & 912 & $5 \%$ \\
\hline 7 & Drugs \& Pharmaceuticals & 6,361 & 5,723 & 3 & 472 & $4 \%$ \\
\hline 8 & Chemicals (Other Than & 3,317 & 9,397 & 118 & 111 & $4 \%$ \\
\hline 9 & Power & 3,937 & 7,473 & 13 & 461 & $4 \%$ \\
\hline 10 & Construction & 6,528 & 12,478 & 105 & 679 & $3 \%$ \\
\hline
\end{tabular}


Graph No: 2. Sectors attracting highest fdi equity inflows

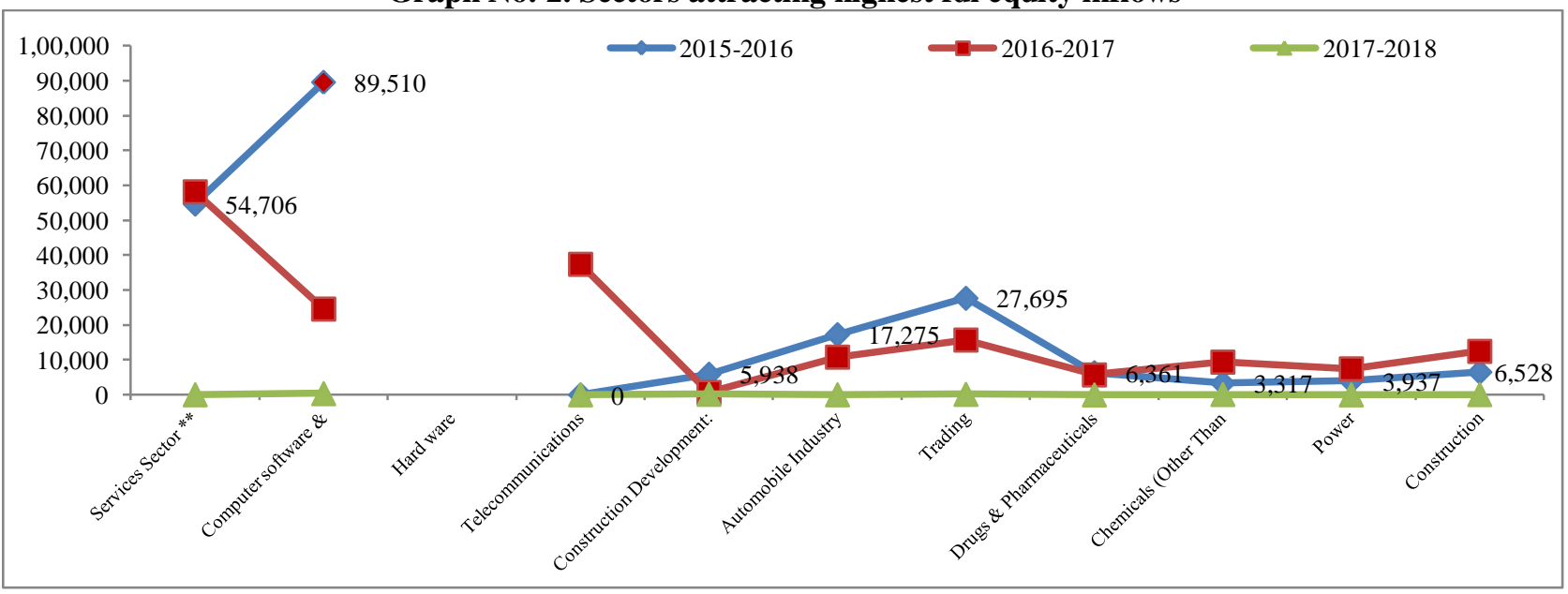

Analysis \& interpretation: The above table and graph shows that highest amount of FDI in service sector in India is highest in the year of 2016-17.the lowest is in India is Drugs \& Pharmaceuticals in the year 2016-17 respectively.

2. To compare FDI inflows during the post liberalization period \& pre liberalization Period:

Formula based analysis:

AGR = (X2- X1)/ X1

$\mathrm{X} 1=1$ value of variable $\mathrm{X}$

$\mathrm{X} 2=2$ value of variable $\mathrm{X}$

Compounded Annual Growth Rate $($ CAGR $)$ formula $=$ $\operatorname{CAGR}(\mathbf{t 0}, \operatorname{tn})=(\mathrm{V}(\mathrm{tn}) / \mathrm{V}(\mathrm{t} 0)) \mathbf{1} / \mathrm{tn}-\mathrm{t0}-\mathbf{1}$

$\mathrm{V}(\mathrm{t} 0)=$ start value

$\mathrm{V}(\mathrm{tn})=$ finish value

tn $-\mathrm{t} 0=$ number of years

Table 1: FDI Inflows during Pre Liberalization Period

\begin{tabular}{|c|c|c|c|}
\hline & \multicolumn{3}{|c|}{ Category -I is Pre-Liberalization Period } \\
\hline $\begin{array}{c}\text { SI } \\
\text { No }\end{array}$ & Year & $\begin{array}{c}\text { Amount (US } \\
\text { Dal. Millions) }\end{array}$ & $\begin{array}{c}\text { Annual Growth } \\
\text { Rate (\%) }\end{array}$ \\
\hline 1 & $1980-81$ & 8.00 & - \\
\hline 2 & $1981-82$ & 10.00 & $25 \%$ \\
\hline 3 & $1982-83$ & 60.00 & $500 \%$ \\
\hline 4 & $1983-84$ & 60.00 & - \\
\hline 5 & $1984-85$ & 60.00 & - \\
\hline 6 & $1985-86$ & 160.00 & $166.7 \%$ \\
\hline 7 & $1986-87$ & 196.00 & $22.50 \%$ \\
\hline 8 & $1987-88$ & 190.00 & $-3.06 \%$ \\
\hline 9 & $1988-89$ & 267.00 & $40.52 \%$ \\
\hline 10 & $1989-90$ & 330.00 & $23.60 \%$ \\
\hline 11 & $1990-91$ & 97.00 & $-70.60 \%$ \\
\hline $\mathbf{1 2}$ & Total & $\mathbf{1 4 3 8}$ & $\mathbf{0 . 6 4 0 6}$ \\
\hline
\end{tabular}

\section{Pre Liberalization Period}

$\longrightarrow$ Annual Growth Rate (\%) -

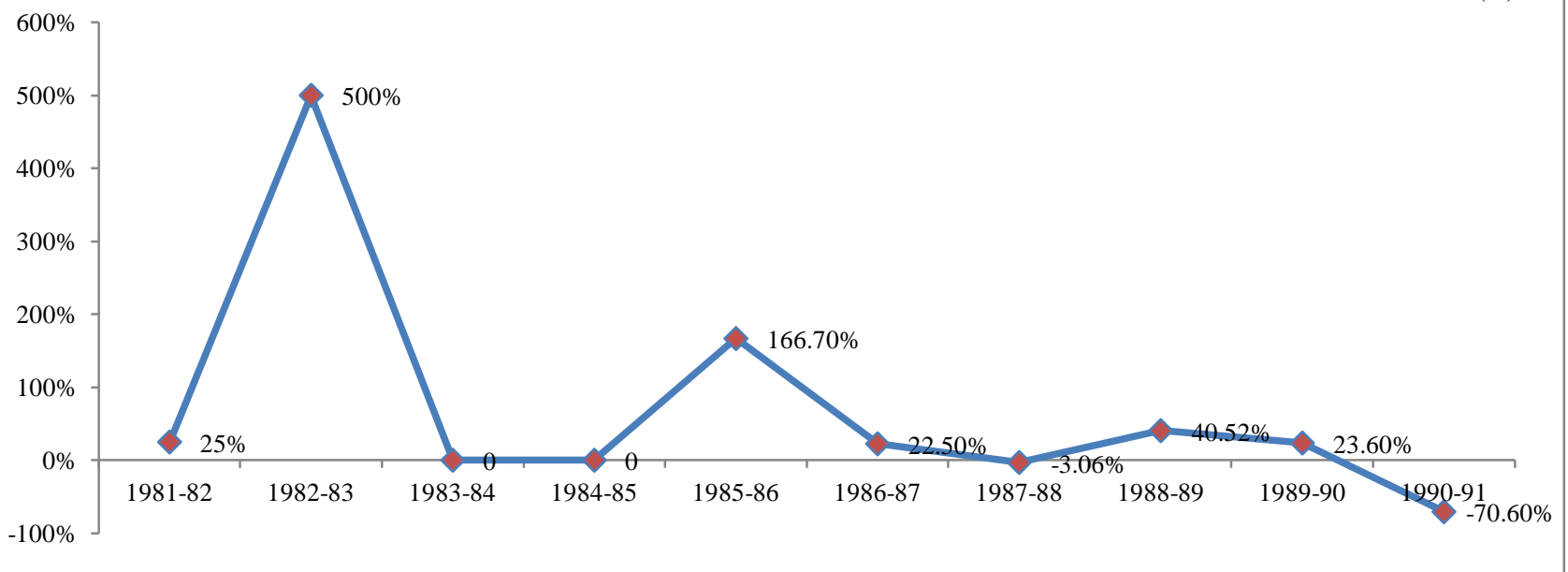

Analysis and interpretation: The above table and chart shows that Foreign Direct Investment inflow into India before 1991(Pre-Liberalization) was minimal with the Compounded Annual Growth Rate showing only 25.46 percent. In this time foreign direct investments into in India was very low and moderately few sectors. The Government of India was introduced Economic reforms in the year of
1991. FDI had suddenly become important for India which was looked upon as a key component of economic reforms package. 
The Pivotal part of Global Direct Investment - A Research Pre \& Post liberalization Era

Table 2: FDI Inflows during Post Liberalization Period Category-II is Post -Liberalization era

\begin{tabular}{|c|c|c|c|}
\hline & \multicolumn{3}{|c|}{ Category-II is Post -Liberalization era } \\
\hline $\begin{array}{c}\text { SI } \\
\text { No }\end{array}$ & Year & $\begin{array}{c}\text { Amount (US Dal. } \\
\text { Millions }\end{array}$ & $\begin{array}{c}\text { Annual Growth } \\
\text { Rate (\%) }\end{array}$ \\
\hline 1 & $1991-92$ & 129 & - \\
\hline 2 & $1992-93$ & 315 & $-144.18 \%$ \\
\hline 3 & $1993-94$ & 586 & $86.03 \%$ \\
\hline 4 & $1994-95$ & 1,314 & $55.40 \%$ \\
\hline 5 & $1995-96$ & 2,144 & $63.16 \%$ \\
\hline 6 & $1996-97$ & 2,821 & $31.57 \%$ \\
\hline 7 & $1997-98$ & 3,557 & $26.09 \%$ \\
\hline 8 & $1998-99$ & 2,462 & $-30.78 \%$ \\
\hline 9 & $1999-00$ & 2,155 & $-12.46 \%$ \\
\hline 10 & $2000-01$ & 4,029 & $86.96 \%$ \\
\hline 11 & $2001-02$ & 6,130 & $52.14 \%$ \\
\hline 12 & $2002-03$ & 5,035 & $-17.86 \%$ \\
\hline
\end{tabular}

\begin{tabular}{|c|c|c|c|}
\hline 13 & $2003-04$ & 4,322 & $-14.16 \%$ \\
\hline 14 & $2004-05$ & 6,051 & $40.04 \%$ \\
\hline 15 & $2005-06$ & 8,961 & $48.09 \%$ \\
\hline 16 & $2006-07$ & 22,826 & $154.72 \%$ \\
\hline 17 & $2007-08$ & 34,835 & $52.61 \%$ \\
\hline 18 & $2008-09$ & 35,180 & $0.99 \%$ \\
\hline 120 & $2009-10$ & 37,182 & $95.69 \%$ \\
\hline 21 & $2010-11$ & 34,847 & $89.68 \%$ \\
\hline 22 & $2011-12$ & 46,556 & $119.81 \%$ \\
\hline 23 & $2012-13$ & 34,298 & $88.26 \%$ \\
\hline 24 & $2013-14$ & 36,046 & $97.75 \%$ \\
\hline 25 & $2014-15$ & 45,148 & $116.18 \%$ \\
\hline 26 & $2015-16$ & 55,559 & $142.97 \%$ \\
\hline 27 & $2016-17$ & 60,082 & $154.61 \%$ \\
\hline 28 & $2017-18$ & 14,550 & $37.44 \%$ \\
\hline & Total & $\mathbf{2 5 6 4 2}$ & $\mathbf{0 . 6 4 0 6}$ \\
\hline
\end{tabular}

Post Liberalization Period $\longrightarrow$ Annual Growth Rate (\%) -

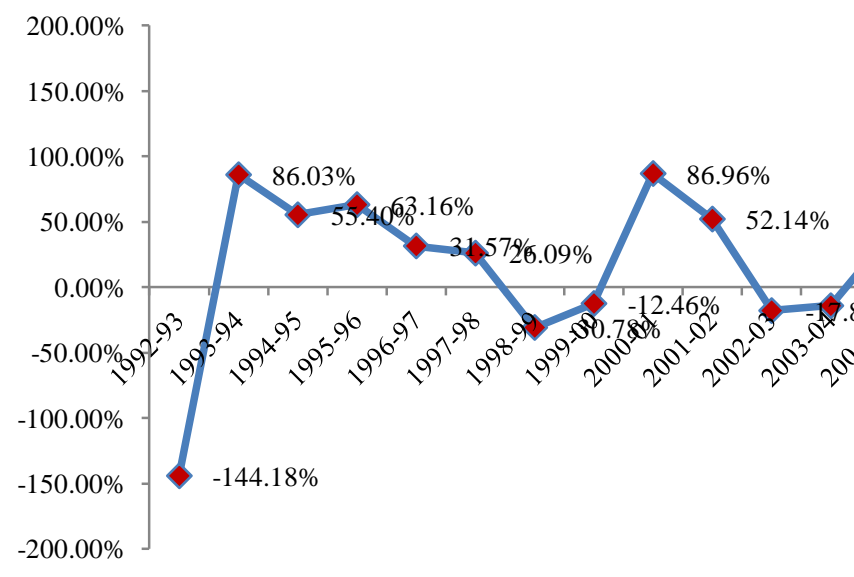

Analysis and interpretation: The above table and chart shows that Foreign Direct Investment inflow into India before 1991(Pre-Liberalization) was minimal with the Compounded Annual Growth Rate showing only 25.46 percent. In this time foreign direct investments into in India was very low and moderately few sectors. The Government of India was introduced Economic reforms in the year of 1991.

Projection of fdi inflows to India:
\begin{tabular}{|c|c|c|c|c|c|}
\hline $\begin{array}{c}\text { SI. } \\
\text { no }\end{array}$ & Model & $\begin{array}{c}\text { Co } \\
\text { efficient }\end{array}$ & $\begin{array}{c}\text { Std. } \\
\text { Error }\end{array}$ & $\begin{array}{c}\text { Student } \\
\text { s test } \\
\text { Value }\end{array}$ & $\begin{array}{c}\text { Probabilit } \\
\text { y Value }\end{array}$ \\
\hline 1 & $\begin{array}{c}\text { ARIM } \\
\text { A-I }\end{array}$ & 1.556 & 0.98 & 8.968 & 0.001 \\
\hline 2 & $\begin{array}{c}\text { ARIM } \\
\text { A-II }\end{array}$ & 0.449 & 0.281 & 3.899 & 0.235 \\
\hline 3 & YEAR & 9898 & 1624 & 3.430 & 0.223 \\
\hline 4 & Const. & $\begin{array}{c}557816.2 \\
5\end{array}$ & $\begin{array}{c}185032.2 \\
0\end{array}$ & 3.334 & 0.228 \\
\hline
\end{tabular}

Global Foreign Direct investment projection for five years

\begin{tabular}{|c|c|c|c|c|c|}
\hline SI no & Year & $\begin{array}{c}\text { Estimated } \\
\text { Amount }\end{array}$ & $\begin{array}{c}\text { Percentage of } \\
\text { Growth }\end{array}$ & $\begin{array}{c}\text { Percentage of Growth } \\
\text { in FDI }\end{array}$ & Confidential Level \\
\hline 1 & $2017-2018$ & $1,90,220$ & 1 & 144102 & $95 \%$ \\
\hline 2 & $2018-2019$ & $2,20,300$ & -2 & 156225 & $95 \%$ \\
\hline 3 & $2019-2020$ & $1,65,500$ & 15 & 168223 & $95 \%$ \\
\hline 4 & $2021-2022$ & $1,88,500$ & -4 & 193221 & $95 \%$ \\
\hline 5 & $2022-2023$ & $2,66,200$ & 06 & 178111 & $95 \%$ \\
\hline 6 & $2023-2014$ & $1,90,000$ & -14.20 & 168665 & \\
\hline
\end{tabular}




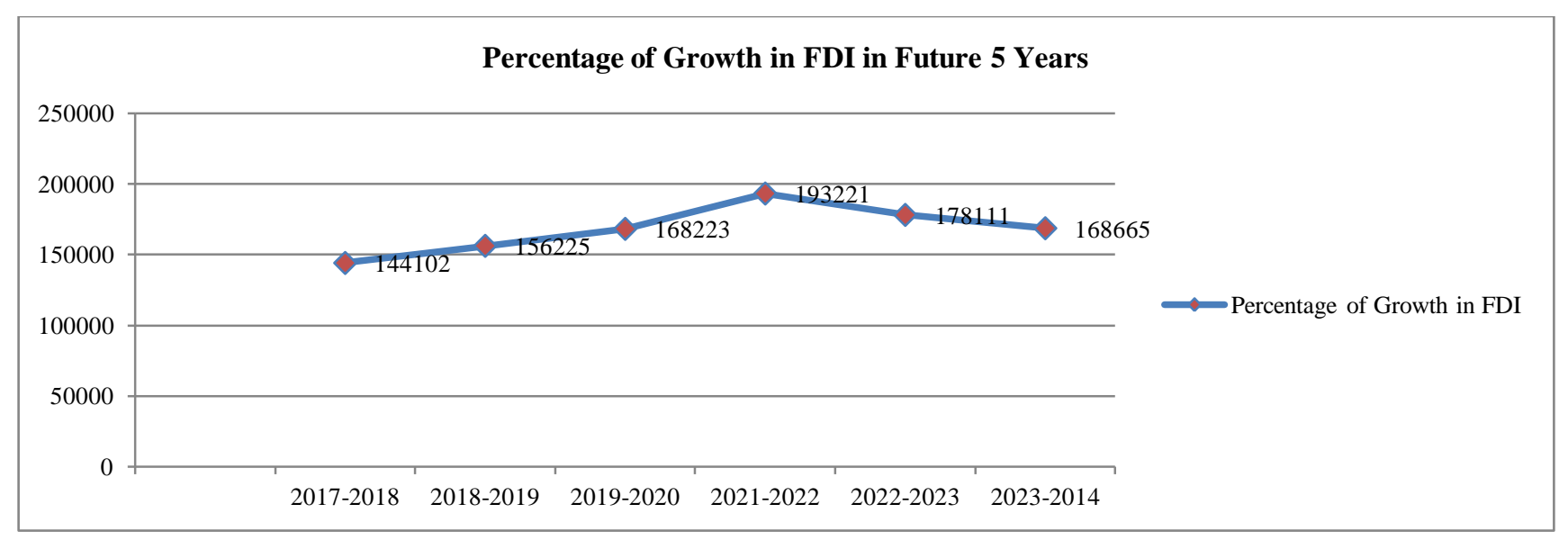

\section{CONCLUSION}

Global investments are playing an important role in the growth of Indian economy better than other nation's economy in the present. More nations are providing more savings and attracting global investments.

The study concludes the titled The Pivotal part of Global Direct Investment - a Study Pre \& post liberalization era has been done based on the secondary data from the period of pre and post liberalization period. The India and China institutional factors are having the stronger influence on the FDI flows. The South African FDI flows are highly influenced by the Quality of public services. Hence, there is further scope of research to do in this area by considering the external factors influence on the Indian fdi flows

\section{REFERENCES}

1. Krishna and Mitra 2015"Trade liberalization, market discipline and productivity growth: new evidence from India." Journal of Development Economics, Vol. 56 (1998) 447-462.

2. Abdul Aziz(2015)Industrialisation:Socio-Economic Externalities and state policy, Concept Publishing Company, New Delhi, 1997 Vol no 15, Issue 4, Pg.no 58-63.

3. Mohan Guru Swamy Sharma(2016)Mohan Guru Swamy Sharma (2005) Foreign Direct Investment in India's Retail Sector; New Delhi.

4. Bary Rose Worth, Avirmons (2016) " Sources of Growth in the Indian Economy" NBER working paper No. 12901. National Bureau of Economic Research, Cambridge.

5. Rao and Singh (2017): - Towards more Effective Movement, Macmillan, Delhi, 2003. 